\title{
Telenovela brasileira
}

Maria Immacolata Vassallo de Lopes*

Professora titular** da Escola de Comunicações e Artes da Universidade de São Paulo (ECAUSP); coordenadora do Programa de Pós-Graduação em Ciências da Comunicação da USP; coordenadora do CETVN - Centro de Estudos de Telenovela da ECA - USP, onde dirige o Projeto Obitel - Observatório Ibero-Americano da Ficção Televisiva.

E-mail: telenovela@usp.br

\section{DISSERTAÇÃO}

FREIRE, Denise de Oliveira. Telenovela e identidade nacional no ciberespaço: explorações metodológicas da recepção internacional de Caminho das Índias em comunidades virtuais. Dissertação (Mestrado em Ciências da Comunicação) - São Paulo: Escola de Comunicações e Artes, Universidade de São Paulo, 2010.

Com o propósito de discorrer em que medida a telenovela brasileira permeia o imaginário do emigrante brasileiro em Portugal, buscamos perceber a interpretação e a construção de novos significados do produto audiovisual no ciberespaço. Elegendo a telenovela como narrativa da nação, procuramos verificar as marcas da identidade nacional presentes nos discursos dos brasileiros em Portugal, pautados por Caminho das Índias, ficção seriada televisiva produzida pela Globo, em comunidades virtuais da nação e da diáspora - os agrupamentos on-line territorializados.

\section{ARTIGOS}

MUNGIOLI, Maria Cristina Palma. Gêneros televisuais e discurso: alguns elementos para análise da série Norma. XXXIII Congresso Brasileiro de Ciências da Comunicação - Intercom - Caxias do Sul-RS, set. 2010. Disponível em: <http://www.intercom.org.br/papers/nacionais/2010/resumos/R5-1971-2.pdf>. Acesso em: set. 2010.

O artigo apresenta elementos para a discussão de transformações que vêm ocorrendo nos gêneros televisuais com a criação/recriação de formatos marcados não apenas pela hibridação, mas também pelo rompimento de um estatuto pragmático por meio do qual os telespectadores reconhecem os gêneros televisuais e as estratégias discursivas presentes notadamente nos gêneros ficcionais. Por meio do instrumental teórico-analítico da Análise do Discurso (AD) e das teorias de linguagem e estética de Bakhtin (2003), são analisados elementos da série Norma, veiculada pela Rede Globo em 2009. 
comunicação \& educação • Ano XVI • número 1 • jan/jun 2011

\begin{abstract}
LIVROS
LOPES, Maria Immacolata Vassallo de; GÓMEZ, Guillermo Orozco (Coord.). Convergências e transmidiação da ficção televisiva: Obitel 2010. São Paulo: Globo, 2010.

O livro dá continuidade ao esforço de um grupo de reconhecidos pesquisadores da comunicação e da cultura no âmbito ibero-americano, que uniram forças e equipes nacionais de trabalho para colocar lado a lado e de forma comparativa as descobertas de um ano de análises da ficção televisiva em nove países. No centro está o acompanhamento das narrativas televisivas em múltiplas plataformas, fenômeno emergente e de grande atualidade.

MARQUES DE MELO, José. Televisão brasileira: desenvolvimento, globalização, identidade - 60 anos de ousadia, astúcia, inovação. São Paulo: Coedição Cátedra Unesco/Umesp de Comunicação, 2010.

Publicação editada com o apoio do Programa Globo Universidade, para distribuição especial aos participantes do CELACOM 2010 - XIV Colóquio Internacional da Escola Latino-americana de Comunicação, como subsídio para os debates realizados na cidade de São Paulo, no período de 17 a 19 de maio de 2010, sobre os 60 anos de televisão na América Latina. Evento promovido pela Cátedra Unesco/Umesp de Comunicação, em parceria com a Cátedra Unesco/ Memorial da América Latina e a colaboração dos Programas de Pós-Graduação das Faculdades de Comunicação da Universidade Metodista de São Paulo (São Bernardo do Campo) e da Universidade Estadual Paulista (Bauru), tendo o incentivo da Fundação de Amparo à Pesquisa do Estado de São Paulo - Fapesp, da Imprensa Oficial do Estado de São Paulo e da TV Unesp.
\end{abstract}

da Pesquisa em Comunicação. Possui experiência na área de Comunicação, com ênfase em Epistemo logia da Comunicação, Teoria da Comunicação e Metodologia da Pesquisa em Comunicação, atuando principalmente nos seguintes temas: campo da comunicação, recepção da comunicação, fiç̧ão televisiva e sociedade da comunicação. 